\title{
Modern Marketing Strategies for Territorial Development: State and Municipal Level
}

\author{
Tatyana Popova*, and Valentina Rudenko \\ Volgodonsk Engineering and Technical Institute Branch of NRNU “MEPhI”, 347360 Volgodonsk, \\ Russia
}

\begin{abstract}
The article reveals the content of the "territorial marketing" concept. The paper's main attention is focused on the fact that nowadays the state and municipal sectors should adhere to key market principles more strictly regarding setting prices, building competitive relations, choosing a target audience, and conducting a communication policy. The idea is substantiated that public sector organizations should be familiar with such concepts as market segmentation and market positioning, the marketing mix and its tools, since even where there is no competition from the private sector, such organizations are forced to compete with each other. The article summarizes the practical experience of territory marketing management, which consists in collecting input data and feedback; monitoring market processes occurring within the state, region or municipality, developing an effective marketing strategy.
\end{abstract}

\section{Introduction}

Territorial marketing has gradually turned into an effective market strategy leading to the economic development of a state, region or a separate municipality. Given the dynamic development of modern society and economy, due to, inter alia, the processes of industrialization and digitalization, the study of territorial marketing has become an urgent need.

Successful area marketing can lead to the creation of a territory brand with many resulting long-term benefits for the region, state and all stakeholders in the process.

Implementation of the territorial marketing strategy using its key tools provides for:

- regulation of operations carried out when crossing the state border;

- protection of the domestic market by increasing the level of competitiveness of domestic producers;

- creation of such an image for a state or region, which has a positive effect on its investment attractiveness;

- use of government agencies, e.g., diplomatic missions, to promote products offered by local manufacturers in foreign markets. [1]

\footnotetext{
*Corresponding author: Tanya930@rambler.ru
} 
There is every reason to believe that territorial marketing is a rather multifaceted concept that includes a number of components in addition to issues of state and regional marketing:

- socially-oriented marketing;

- legislative regulation of marketing activities;

- tax marketing as an innovative product of tax competition;

- compliance with product quality standards;

- budget marketing, etc.

The use of traditional and innovative tools of territorial marketing serves as the basis for the formation of internal advantages of a particular region or a state as a whole, increasing the level of their investment attractiveness.

\section{Materials and Methods}

States, regions, cities in the process of new industrialization and digitalization are increasingly using data-driven solutions, social media platforms and digital marketing strategies to reach their target audiences. All this contributes to the development of marketing communications, raising awareness of potential consumers, saving money and time to attract them, and conducting political campaigns.

It is vital for government agencies not only to adapt to the rapidly changing technological climate, but also to harness and benefit from these changes. Digital marketing can bring endless benefits to government agencies, from raising awareness of the local population to communicating in crisis situations.

Traditional marketing and outreach is expensive, while using the functionality of costeffective digital platforms (social media or a highly functional website) can significantly raise awareness of issues affecting the public in a municipality, region or state as a whole. All this, in view of the fact that most people are already using these platforms, allows for a more massive, yet targeted approach.

Digital platforms have changed the way government organizations communicate during emergencies. It is currently difficult for first responders and officials to disseminate information using traditional communication channels (radio or television).

Platforms like social media also build trust among audiences by exhibiting a certain level of transparency. Trust in general is important for the target audience, but it is extremely important when it comes to public opinion about whether a government institution takes into account the interests of citizens.

Moreover, digital marketing offers a fast and relatively inexpensive way to test various messages among the population (e.g., slogans of ongoing political campaigns). It does not cost too much to launch a marketing campaign to study public opinion in a modern digital format, but at the same time, state or local authorities receive valuable instant feedback.

But with all the seemingly extremely positive results of using digital marketing in addressing issues of territorial development, there are some negative nuances. [2]

Employees engaged in digital marketing in government agencies face many organizational barriers that can be as complex as technical ones. These barriers can prevent digital activities from having a positive impact on the result. These barriers include the following:

Even modest digital marketing efforts are subject to many procedural constraints, many of which are devised and for good reason. To ensure compliance with regulatory requirements, government agencies must implement many bureaucratic procedures, go through multi-level approval processes, and are forced to comply with strict principles. Sometimes all of these procedures can take up a lot of valuable time. 
Passing multiple approval points requires careful planning, management, and documentation, rather than development and testing. Failure to comply with these rules can delay the project, increase costs or lead to its complete cancellation, and implementation does not guarantee success.

Government agencies also face challenges with regard to costs and selection of digital software service providers, which lengthens the procurement process. This causes technology, which might be advanced at the time of order, to become obsolete by the time it is introduced.

Most government agencies have limited flexibility when it comes to digital projects. On top of that, potential investors are skeptical about funding proposals due to the likelihood that government projects will fall behind schedule or go beyond the original budget. Together, these problems make it difficult for government agencies to acquire and implement new technologies or projects that can help in the transition to a digital marketing environment. [6]

\section{Results and Discussion}

In recent years, marketing has sufficiently strengthened its position in state and municipal administration. Modern scientists consider it as a set of certain technologies and a set of efforts undertaken by authorities at various levels of government in order to maintain and develop their activities.

Like private firms, government agencies identify their customers, design services, set prices, design distribution and delivery systems, and communicate the effectiveness and availability of offerings. However, public sector organizations and private ones differ to a great extent. These differences create unique marketing challenges that require unique marketing solutions. The toolkit of these solutions is constantly expanding and improving in view of the development of the digital environment.

The economic environment is changing rapidly. To remain attractive to established companies and attract new types of economic activity, cities and regions need to have a reliable marketing strategy and a comprehensive marketing plan, and to conduct effective marketing communication interaction.

A holistic economic vision and the development of sound business concepts to improve the regional business climate are critical to a successful marketing strategy. [5]

At the regional level, the focus of the marketing strategy is on the development of business locations / sites / office parks / science parks / campuses. Concept development is followed by a feasibility study followed by the implementation of the new business concept / location and marketing organization.

\section{Conclusions}

1. What happens in the public sector has serious consequences for the economy (both positive and negative). The public sector is the non-privately owned part of economic life that produces, delivers and distributes basic public goods and services at the national, regional or local levels. In the new economic conditions, the public sector cannot do without territorial marketing tools.

2. Each region is different from the rest. Regions may be close to each other, but for most, ethnic composition, age demographics, geography, culture, business structure, and social fabric can be quite different. All this can impede effective interaction and communication between government structures and various communities. Regional governments' marketing strategies require a deep 
understanding of local communities and the people who live in them, coupled with knowledge of which are the best marketing communications tools to use.

3. Based on a client-centered philosophy, reforms in government structures, public administration and public finances should aim to help governments become more flexible, mobile and better meet individual needs. In particular, this shift towards a philosophy based on marketing engagement has spurred changes that transform the civil service from a policymaker to a provider of quality public goods and services; creating new opportunities for financing the activities of the public sector and its services.

\section{References}

1. E.V. Anokhin, V.A. Anokhin, Practical Marketing, 8(222), 3 (2005)

2. I.A. Ashmarov, S.M. Karandeev, Region: Systems, Economics, Management, 2, 1619 (2005)

3. V.I. Belyaev, Territory Marketing: Methods and Techniques of Substantiation of Strategic Decisions of Regional Development: Monograph, 244 (2015)

4. G.V. Vorontsova, F.T. Gazgireeva, NaukaPark, 9, 18 (2015)

5. T.S. Popova, A.A. Maksaev, Practical Marketing, 12(274), 28 (2019)

6. V.A. Bondarenko, I.N. Efremenko, A.A. Manjula, M. Smokova, Advances in Intelligent Systems and Computing, 1100 AISC, 706 (2020)

7. V.A. Bespalko, A.A. Voronov, O.V. Martynenko, International Journal of Economics and Business Administration, 7, S1. 403 (2019)

8. F. Kotler, Marketing Places: Attracting Investment, Industry and Tourism to Cities, States and Nations, 388 (1993)

9. D. Medway, G. Warnaby, European J. of Marketing, 641 (2008) 